\title{
The Effect of Applying Imperial Research on Sustainable Industrial Areas (SIA) Approach
}

\author{
Eng-Samah Ahmed Sayed ${ }^{1}$. Prof. Dr Ahmed Aouf ${ }^{2}$. Dr Tamer Abd Elazizi ${ }^{3}$
}

\begin{abstract}
Industry plays an important role in the economic life of all developed nations, however, sometimes industry might have bad effect on the environment, making it necessary to plan industrial areas so that they are economically sustainable. There are many sustainability indices that were developed after the turn of the century to achieve sustainable industrial areas such as (SIA) by (UNIDO) United Nation Development Organization.
\end{abstract}

This research represents and analyzes successful experiments of two eco-industrial parks (EIP) one in Canada (Hinton) and the other in South Korea (Ulsan) which implement the (SIA) Sustainable Industrial Areas requirements to decrease the negative impacts of industry and create eco-industrial parks (EIP).

in addition to the salient importance of the economic, social, and environmental aspects in planning industrial areas, management factors are more than necessary in planning any eco-industrial park as appears in Sustainable Industrial Area (SIA) framework. This research paper focuses on creating an improved structure for the (SIA) system and a proposal for a formula for application to industrial areas to be (EIP) ecoindustrial parks.

Keywords: ( SIA) sustainable industrial areas, (ECO) eco industrial parks, Economic aspects, Social aspects, Administrative aspects.

\section{INTRODUCTION}

Eco-industrial parks can be defined as a set of businesses within a specific geographic area which share resources and thereby increase profitability, reduce environmental impact [1]. and improve social performance. The concept of eco-industrial parks emerged during the 1990s in the context of industrial ecology [2].

In this regard, compliance with national and local regulations is the baseline for all industrial parks, whatever the geographical location and specific characteristics of the park. Eco-industrial parks therefore should go beyond compliance with local and national regulations on environmental and social requirements [3].

\section{BACKGROUND OF ECO-INDUSTRIAL PARKS}

An eco-industrial park (EIP) is proposed as one of the approaches towards sustainable economy, contrary to product or firm-specific sustainability approaches. (EIPs) have a much larger scope. Their influence stretches over three different levels the firm, across firms, regional and global [4].

Analysis of existing industrial parks in Canada (Hinton) and the other in South Korea (Ulsan) EIP can substantially reduce waste and resource consumption over their life cycle [5].

Despite the promises of the EIP concept, the large number of unsuccessful EIP initiatives in the USA and Europe indicate that planned EIP development is challenge [6].

Some of these challenges are related to planning stage such as large scale infrastructure prqiect, geographical obstacles and managing complex stakeholder relationships, others can be found in implementation stages such as relationships between EIP participants, called industrial symbiosis [7]; pp.987-988], Current research suggests that initiatives by governmental acts alone, without the support of firms, do not lead to successful EIP development [8].

\subsection{Research Objectives}

1-Represent the planning principles and standards that should be followed in planning industrial park from a global perspective SIA (sustainable industrial areas) which includes the administrative, economic, environmental and social aspects in order to reduce the effects of pollution resulting from industrial areas.

2-Evaluate the application of (SIA) sustainable industrial area on certain cases such as (Hinton) in Canada and the other is (Ulsan) in South Korea.

3-Formulate an improved approach to the global framework, which is sustainable industrial area (SIA) to achieve Echo-Industrial Park (EIP) within the industrial zones.

\footnotetext{
${ }^{1}$ Director of Project Implementation Follow-up Department and Preparing PHD thesis in Cairo University, samahahmed46@yahoo.com.

2 Professor of Architecture and Urban Design - Department of Architecture, Cairo University, a.ouf@urban -edge.net

${ }^{3}$ Associate Professor of Architecture and Urban Design - Department of Architecture, Cairo University,Drtameraa@yahoo.com
} 
International Journal of Engineering Research and Technology. ISSN 0974-3154, Volume 13, Number 11 (2020), pp. $3194-3207$

(C) International Research Publication House. https://dx.doi.org/10.37624/IJERT/13.11.2020.3194-3207

\section{1-3- Methodology}

As mentioned, the research was designed to develop the sustainable industrial areas (SIA), as well as studying two experiments (Hintonin in Canada) and( Ulsan, South Korea), then analyzing and evaluating them according to sustainability criteria such as administrative, economic, environmental and social aspects, from its benefits, we can Formulate the development improving of the sustainable industrial area (SIA) framework.

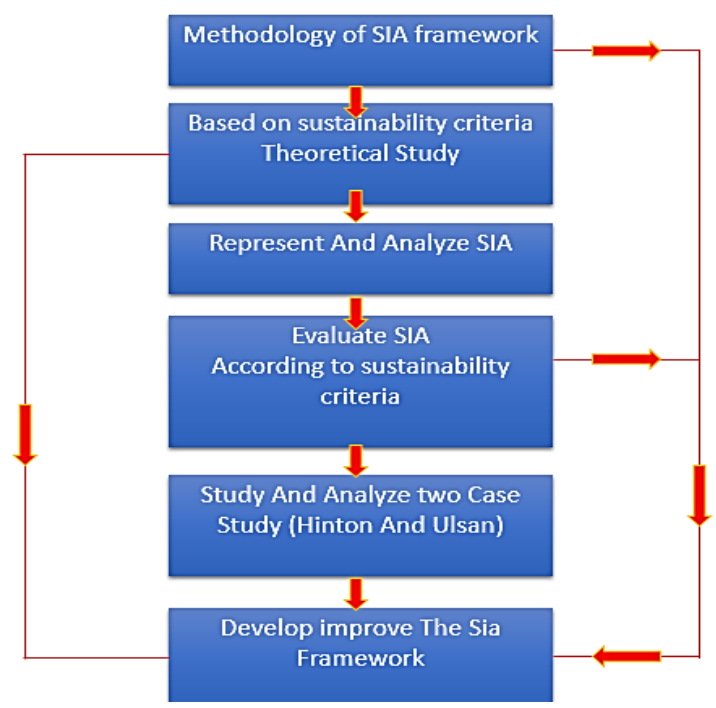

Fig.1. the designed methodology (source: author's (2020)

\section{2-1- (SIA) Criteria}

SIA framework describes the performance requirements for EIP centers according to four key Categories:

Park Management Performance, Environmental Performance, Social Performance, and Economic Performance. Fig.1. presents the overarching framework. This framework provides the basis for defining and setting prerequisites and performance requirements for EIPs as a baseline. EIPs must comply with all applicable local and national regulations [9].

\section{The SIA Framework Includes:}

- Park management performance which consists of park management services, monitoring, planning and zoning.

- Environmental performance consists of environmental management and monitoring, energy management, water management, waste and material use, natural environment and climate resilience.

- Social performance consists of social management and monitoring, social infrastructure, community outreach and dialogue.

- Economic performance consists of employment generation, local business and some promotion.

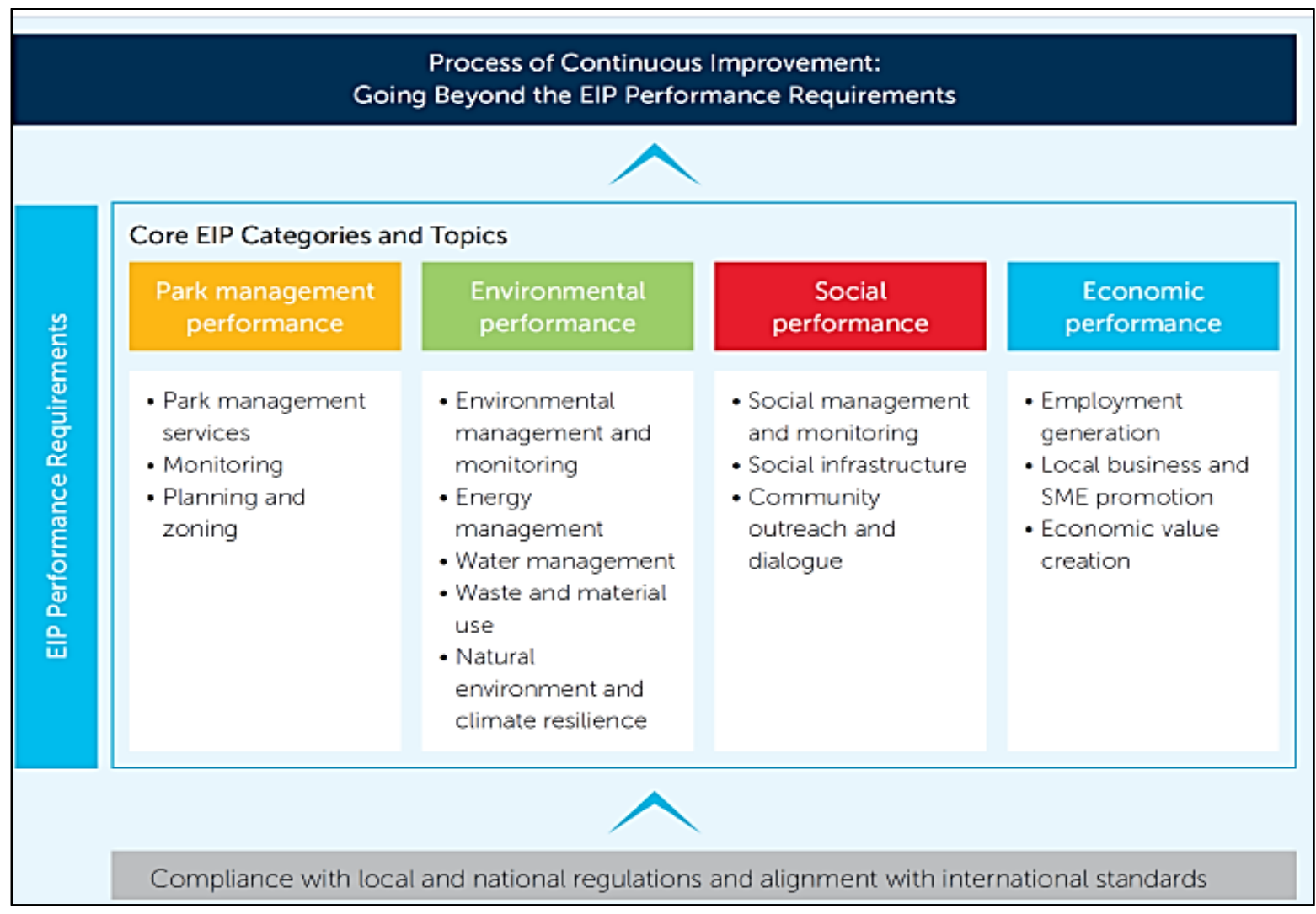

Fig.2. Compliance with local and national regulations and alignment with international standards SIA criteria international framework" 


\section{2-2- Park management: Performance requirements for Eco-} Industrial Parks [10]

Park management is the most important item in ( $\mathrm{SiA})$ because having a formalized, well-functioning and economically sustainable park management structure can deliver a range of benefits:

- $\quad$ Single entity in charge leads to efficiency gains.

- Single entity driving strategy for clean production and social standards helps to meet expec tations in attracting investments.

- Identifying synergies and opportunities for collaborative approaches among park firms, as well as in achieving mutual environmental and social goals and targets.

- A dedicated entity to disseminate knowledge about available new technologies and successful interventions.

Table .1 -Park management Performance requirements

\begin{tabular}{|c|c|c|c|}
\hline Topic & Sub-topic & Description/Requirement & Prerequisites for park management \\
\hline \multirow[t]{2}{*}{$\begin{array}{l}\text { 1-park } \\
\text { management } \\
\text { services }\end{array}$} & Park management entity & $\begin{array}{l}\text { - park planning operations } \\
\text {-management } \\
\text {-monitoring }\end{array}$ & $\begin{array}{l}\text {-park planning operations } \\
\text {-management } \\
\text {-monitoring }\end{array}$ \\
\hline & $\begin{array}{l}\text { Park property common } \\
\text { infrastructure and } \\
\text { services }\end{array}$ & $\begin{array}{l}\text {-facilitates common services } \\
\text {-infrastructure } \\
\text {-smooth operations. }\end{array}$ & $\begin{array}{l}\text {-land use monitoring } \\
\text {-plot allotments ,utilities, roads, waste, } \\
\text { wastewater treatment, power \& energy } \\
\text { systems, waste collection areas, maintenance, } \\
\text { repair workshops, security } \\
\text { common landscaping, buffer zones, street } \\
\text { lighting, security surveillance, } \\
\text { street cleaning, common employee, tenant } \\
\text { facilities. } \\
\text { networking, collaboration, training } \\
\text { opportunities, engagement with the park's } \\
\text { stakeholders. }\end{array}$ \\
\hline \multirow[t]{3}{*}{$\begin{array}{l}\text { 2-monitoring and } \\
\text { Risk management }\end{array}$} & \multirow[t]{2}{*}{$\begin{array}{l}\text { Monitoring performance } \\
\& \text { risks }\end{array}$} & $\begin{array}{l}\text {-monitoring achievement EIP } \\
\text {-management of critical risk }\end{array}$ & $\begin{array}{l}\text {-progress on environmental, social, } \\
\text { economic, } \\
\text { - critical risk factors, risk points, accidental } \\
\text { release of poisonous solid, liquid, gaseous } \\
\text { effluents, } \\
\text { fire hazards are possible, } \\
\text { - applicable natural disaster risks. }\end{array}$ \\
\hline & & $\begin{array}{l}\text {-climate change } \\
\text { to be prepared prior disaster }\end{array}$ & $\begin{array}{l}\text {-possible negative impacts due to climate } \\
\text { change risks -all adaption needs for } \\
\text { infrastructure, services } \\
\text {-climate change risks. } \\
\text { - potential damages. }\end{array}$ \\
\hline & $\begin{array}{l}\text { Information } \\
\text { applicable } \\
\text { regulations and } \\
\text { standards }\end{array}$ & $\begin{array}{l}\text {-regulations and international } \\
\text { standards applicable. }\end{array}$ & $\begin{array}{l}\text {-local/national regulations. } \\
\text {-international standards applicable to } \\
\text { industrial park. } \\
\text {-management entity. }\end{array}$ \\
\hline $\begin{array}{l}\text { 3- planning and } \\
\text { zoning master } \\
\text { Plan. }\end{array}$ & Master plan & $\begin{array}{l}\text {-planning } \\
\text { - zoning master plan }\end{array}$ & $\begin{array}{l}\text { - site selection study based on various risk } \\
\text { analyses. } \\
\text {-Efficient infrastructure, utilities, and } \\
\text { transportation network, - internal park, buffer } \\
\text { zone, procedure to safely locate high risk } \\
\text { industries\& cluster synergistic industries. }\end{array}$ \\
\hline
\end{tabular}

From the text above we extract that park management did not include several important items for the references in (topic 1) park management services such as and how to deal with problems also in (topic3) planning and zoning master Plan are suffering from shortage of data about future extension for the industrial areas and clear future vision for land use planning. 


\section{2-3- Environment: Performance requirements [10]}

Environmental performance includes management and mitigation of potential adverse environmental impacts, entails introduction of low/zero carbon energy generation \& resourceefficient production processes.
Typical key environmental themes: pollution prevention, resource efficiency, clean production, industrial symbiosis and synergies, water, waste \& energy management.

- Pollution prevention systems must be introduced to mitigate toxic nature of any industrial production \& operation.

Table .2- Environmental performance requirements

\begin{tabular}{|c|c|c|c|}
\hline topic & Sub-topic & Description/Requirement & $\begin{array}{l}\text { Prerequisites for park } \\
\text { management }\end{array}$ \\
\hline $\begin{array}{l}\text { 1-management } \\
\text { monitoring }\end{array}$ & $\begin{array}{l}\text { Environmental, } \\
\text { energy management } \\
\text { Systems }\end{array}$ & $\begin{array}{l}\text { ISO } 14001 \text { environmental } \\
\text { management standard, } \\
\text {-ISO 50001 energy } \\
\text { management standard, } \\
\text {-energy waste, material use water, } \\
\text { point source } \\
\text { emissions. }\end{array}$ & $\begin{array}{l}\text { - an environmental, energy } \\
\text { management } \\
\text { system } \\
\text { - monitoring park performance } \\
\text { \& supporting resident firms. }\end{array}$ \\
\hline \multirow[t]{2}{*}{ 2- Energy } & Energy efficiency & $\begin{array}{l}\text { - energy efficiency strategies } \\
\text { management } \\
\text {-infrastructure } \\
\text { - major energy consuming resident } \\
\text { firms. }\end{array}$ & $\begin{array}{l}\text { - supporting programs } \\
\text { - improve the energy } \\
\text { efficiency. }\end{array}$ \\
\hline & $\begin{array}{l}\text { Exchange of waste heat } \\
\text { Energy }\end{array}$ & $\begin{array}{l}\text { opportunities for common energy } \\
\text { and heat exchange networks. }\end{array}$ & $\begin{array}{l}\text {-investigate opportunities for } \\
\text { heat and energy recovery. }\end{array}$ \\
\hline 3-Water & $\begin{array}{l}\text { Water efficiency, reuse } \\
\text { and recycling }\end{array}$ & $\begin{array}{l}\text {-water-saving } \\
\text { - re-use plans }\end{array}$ & $\begin{array}{l}\text {-increase water reuse } \\
\text { - reuse of industrial effluents. } \\
\text { - rainwater, storm water } \\
\text { collection. }\end{array}$ \\
\hline \multirow[t]{2}{*}{$\begin{array}{l}\text { 4-Climate change and the } \\
\text { natural environment }\end{array}$} & $\begin{array}{l}\text { Air, ghg emissions and } \\
\text { pollution prevention }\end{array}$ & $\begin{array}{l}\text {-low-carbon energy } \\
\text {-efficiency measures, } \\
\text { - waste heat to reduce ghg } \\
\text { emissions. }\end{array}$ & $\begin{array}{l}\text {-minimize ghg emissions, such } \\
\text { as carbon dioxide (co2), } \\
\text { methane (ch4), nitrogen oxide } \\
\text { (nox). }\end{array}$ \\
\hline & $\begin{array}{l}\text { Environmental } \\
\text { assessment } \\
\text { ecosystem services }\end{array}$ & $\begin{array}{l}\text {-protection of the sensitive natural } \\
\text { environment. }\end{array}$ & $\begin{array}{l}\text { - a plan in place to assess } \\
\text { operational environmental } \\
\text { impacts, and aims to } \\
\text { limit the impact on prioritized } \\
\text { local ecosystem services }\end{array}$ \\
\hline
\end{tabular}

From the text above we extract that the environment Performance did not includes several important items for the references in (topic 1) management and monitoring such as noise control, monitor natural sites and also in (topic 4) climate change and natural environment is ignoring landscape planning and its effect on recommending sorts of planting planning an important role in get rid of harmful in issions (if existed).

This study is also ignoring the criteria must be followed to plan the residential areas and its relationship with the industrial area such as (distance between them, services included, landscaping as fencing).

\section{2-4- Social: Performance Requirements for Eco-Industrial Parks [9]}

SIA ensure implementation of good social management practices, decent work, social \& community infrastructure, maintaining good relationships with local community and aiming to adopt good international practice across park and firms.

Social performance is an indicator of its inclusiveness, local employee/community welfare and equal opportunities.

- Park management ensure that SIA reflects good practice with regard to social management practices across firms \& activities, comply with all client and investor requests, apply social safeguards to upstream \& downstream value chains. 
- $\quad$ SIA minimizes adverse social impact on work force \& local community;

- Better integration of social conditions for workers \& community contribute to a more resilient \& efficient industrial park;

- Integrating a proactive approach to tackle social risks and enhance reputation \& relations with community, investors $\&$ customers.

Table .3 Social Performance Requirements

\begin{tabular}{|c|c|c|c|}
\hline Topic & Sub-topic & Description/Requirement & $\begin{array}{l}\text { Prerequisites for } \\
\text { park management }\end{array}$ \\
\hline $\begin{array}{l}\text { 1-Social } \\
\text { management } \\
\text { Systems }\end{array}$ & Management team & $\begin{array}{l}\text {-ensuring social infrastructure. } \\
\text { - monitoring. } \\
\text { - managing social information }\end{array}$ & $\begin{array}{lr}\text {-plan } & \text { \&manage } \\
\text { social } & \text { quality } \\
\text { standards } & \end{array}$ \\
\hline $\begin{array}{l}\text { 2-Social } \\
\text { infrastructure }\end{array}$ & $\begin{array}{l}\text { Primary social } \\
\text { Infrastructure }\end{array}$ & $\begin{array}{l}\text {-fundamental social } \\
\text { infrastructure } \\
\text {-lavatories and public toilets } \\
\text { (for men and women), } \\
\text { - drinking water fountains, } \\
\text { - cafeterias } \\
\text {-recreational areas, } \\
\text { - childcare programs. }\end{array}$ & $\begin{array}{l}\text {-social } \\
\text { infrastructure }\end{array}$ \\
\hline
\end{tabular}

From the text above we extract that the social performance did not including several important items in (topic 1) Social management Systems is ignoring how to achieve social equity between the resintents from the different social classes (managerid level and labor level), And also in (topic 2) Social infrastructure there is absence of humity aspect in this study such as (shaded paths, pergolas, sitting areas and public spaces) and also training, staff housing and baby daycare.

\section{2-5- Economic performance requirements [10]}

Industrial parks are an important vehicle used by governments to boost their manufacturing sector and to add value to the economy.

- SIA provides economic gains \& competitive advantages, offer employment generation opportunities, industrial added value and linkages with local business.

Table .4 Economic Performance Requirements

\begin{tabular}{|l|l|l|l|}
\hline Topic & Sub-topic & Description/Requirement & Prerequisites for park management \\
\hline $\begin{array}{l}\text { 1-Employment } \\
\text { generation }\end{array}$ & Type of employment & $\begin{array}{l}\text {-provide opportunities for } \\
\text { long-term employment }\end{array}$ & $\begin{array}{l}\text {-specific numbers and types of jobs } \\
\text {-including diversity \& } \\
\text { inclusiveness } \\
\text { - government targets. }\end{array}$ \\
\hline $\begin{array}{l}\text { 2- local business and } \\
\text { SME } \\
\text { Promotion }\end{array}$ & SME development \\
\hline $\begin{array}{l}\text { 3- Economic value } \\
\text { creation }\end{array}$ & $\begin{array}{l}\text { Market demand for EIP } \\
\text { Services and } \\
\text { infrastructure }\end{array}$ & $\begin{array}{l}\text { - green infrastructure, services } \\
\text {-ensure economic feasibility. }\end{array}$ & $\begin{array}{l}\text {-market demand } \\
\text {-feasibility study. } \\
\text { - green infrastructure, } \\
\text { service. }\end{array}$ \\
\cline { 2 - 4 } & $\begin{array}{l}\text { EIP meets economic } \\
\text { interests of the } \\
\text { government }\end{array}$ & $\begin{array}{l}\text {-achieving government targets, } \\
\text { - investment, foreign direct } \\
\text { investment. } \\
\text {-tax revenue targets }\end{array}$ & $\begin{array}{l}\text {-tracked by the park management entity. } \\
\text {-government targets, } \\
\text { - foreign direct investment, } \\
\text { and tax revenues. }\end{array}$ \\
\hline
\end{tabular}

From the text above we extract that - economic performance did not include several important items for the references in (topic.3) Economic value creation is ignoring an important item such as secondary water resources, long-term maintenance, and natural energy. 


\section{3- SIA CASE STUDIES}

\section{3-1- INNOVISTA}

\section{3-1-1- Introduction \& overview [11]}

Site size: 108 acres Greenfield site, with 32 acres of parks and ecological reserves, the site will be developed in three phases, the first phase contains 10 lots range in size 2 acres to 7 acres.

Location: located on highway 16 at the eastern entrance to Hinton, Alberta. It's the gateway to the east of City of Edmonton and west of Jasper National Park.

It is a valuable and highly attractive location given its extraordinary environment spectacular mountain views and its well-exposed and convenient location.

Land use: Zoned M-E1 (Eco-Industrial District) [12].

\section{Three Phases of Innovista}

Innovista is divided into three phases (light industry, heavy industry, and easiest public access), each area is designed to display a preferred character, level of performance or type of land uses, the diagram below (Fig.4) indicates the suggested type of development within each phase. However, the town is open to any innovative development for the Eco-Industrial Park [13] .

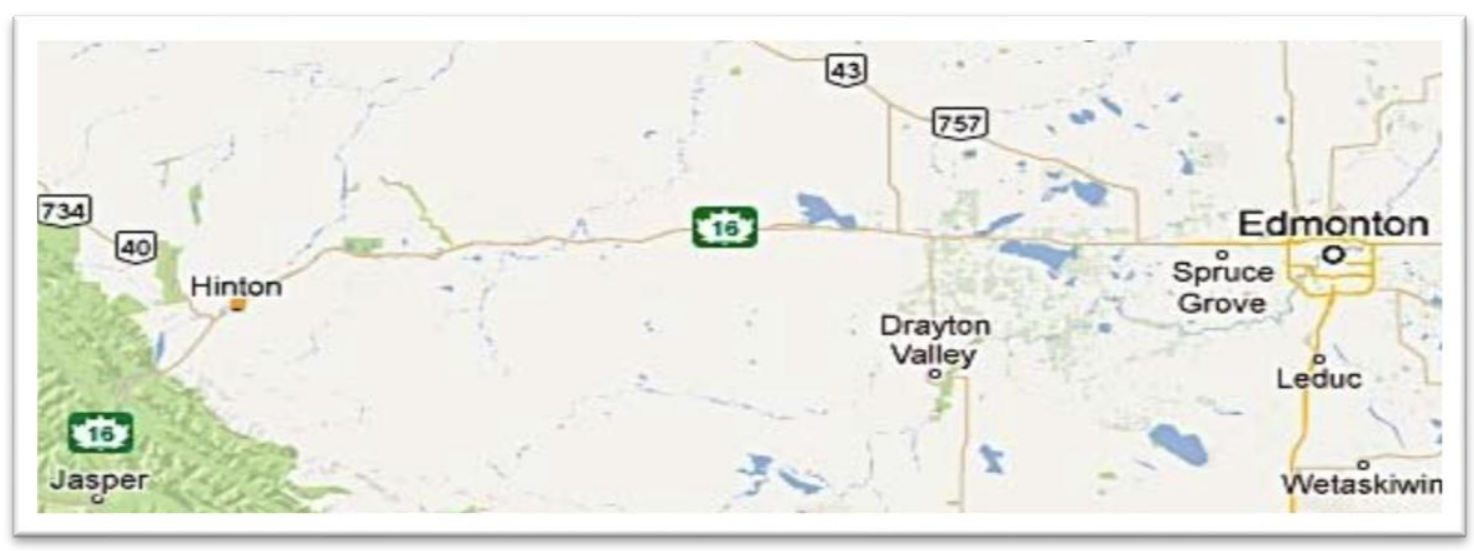

Fig. 3. Innovista Eco-Industrial Park Hinton

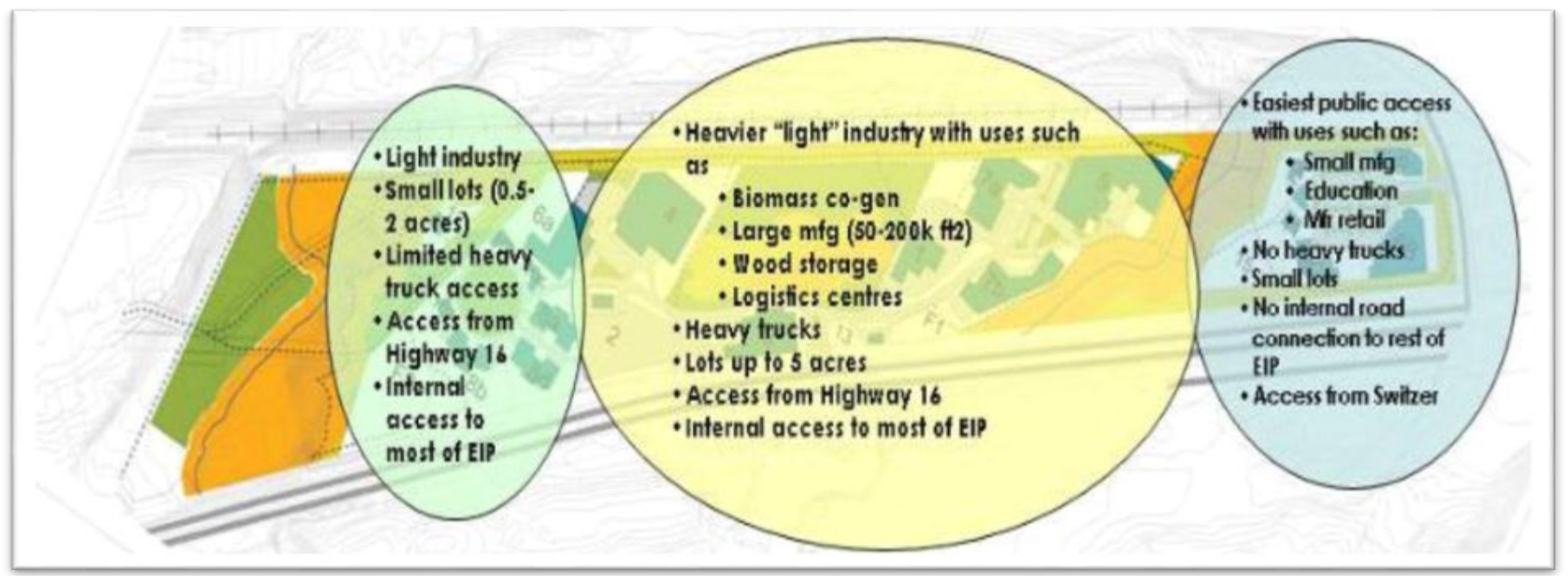

Fig. 4. Three phases of Innovista

\section{3-1-2-SIA performance and impacts}

\section{- Park management performance:}

By comparing management criteria in the case of Innovista with theoretical management performance requirements represented in EIP, we found that: 1-management and monitoring as shown in table 1:

- Creating employment opportunities in large proportion due to the presence of projects.

- Require businesses to identify by-product synergy and resource sharing opportunities in the pre-development planning stage. 
- Planning and zoning master Plan as shown in table 1: Innovista is divided into three phases (light industry, heavy industry, and easiest public access), each area is designed to display a preferred character[11].

\section{2- Environmental performance:}

By comparing management criteria in the case of Innovista with theoretical environmental performance requirements represented in EIP, we found that:

Innovista's natural environment and landscape is one of its defining attractions. Landscape design is an opportunity to create a pleasing business environment, maintain the natural character of the site, and protect its ecological integrity.

2- Energy, 3- water as shown in table 2:

- Landscape design can contribute to the efficiency of energy and water systems, and provide habitat for wildlife.

- Utilize green infrastructure, and continue landscaped areas with adjacent lots with the long-term goal of selfsufficiency with respect to energy, water, and waste management.

- Require at least $40 \%$ permeable surface for every lot through the use of landscaping, green roofs and porous pavement.

- $\quad$ Produce on-site energy from renewable sources or via cogeneration.

- Consider systems to use non-potable water sources where appropriate in industrial processes, wetland flow stabilization and irrigation.

- Optimize the development area to protect existing vegetation (especially mature trees). At least $20 \%$ of site will be landscaped using retention of natural vegetation and replanted with native species.

- Implement opportunities to produce on-site energy from renewable sources (solar, geo-exchange [earth energy], wind, and biomass) or via co-generation.

- Consider the provision of roof run off storage and distribution to provide temporary non-potable water supplies. Where roof runoff is to be maximized for on-site use, use roofing materials that do not yield contaminants into run off.

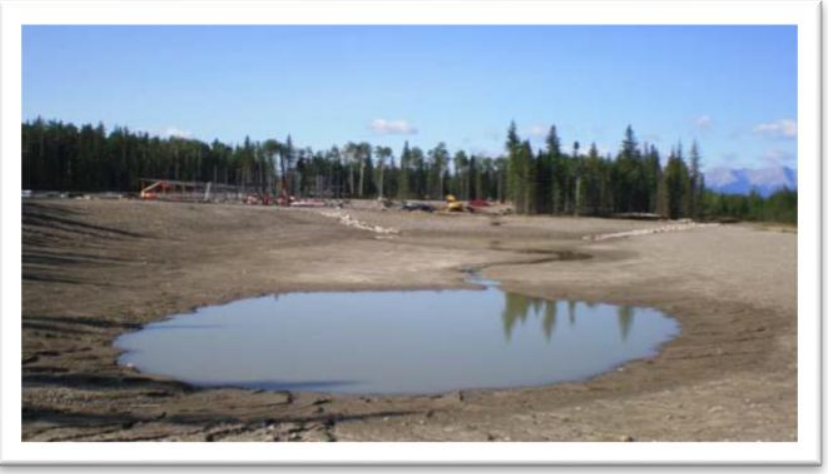

Fig. 5 Storm water management pond is integrated with ecological reserve and trail system.

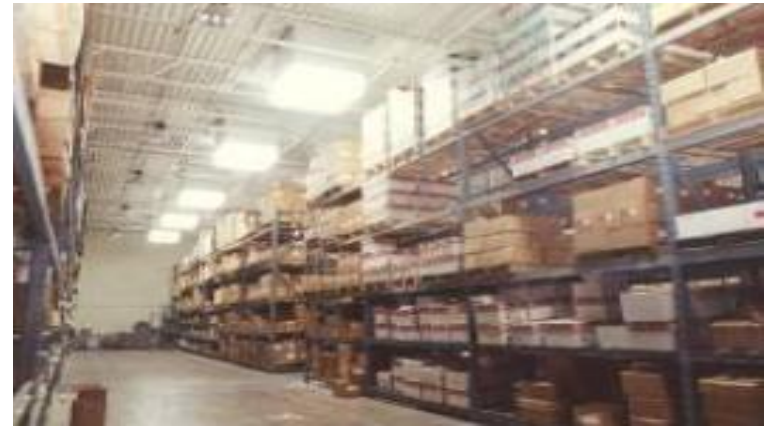

Fig. 6 Example of an effective solar strategy Innovista ecoindustrial park development guidelines Hinton

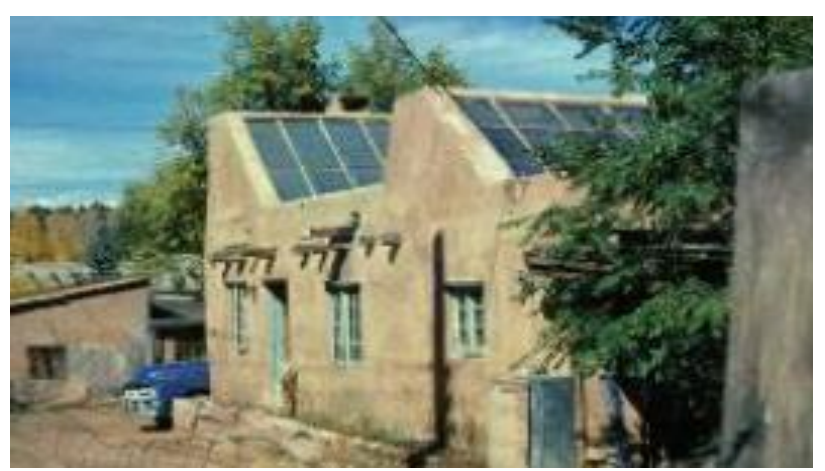

Fig. 7 Example of an effective solar strategy Innovista ecoindustrial park development guidelines Hinton.

- $\quad$ Minimize lighting energy demand by minimizing lighting, using high-efficiency luminaires and bulbs, and maximizing user control [13].

Wastewater System

- The sanitary sewer system Innovista uses is a Small Bore Sewer system (SBS).

- The SBS is a watertight small diameter wastewater collection system designed specifically to contain and direct a predominantly solids-free liquid effluent by gravity through small diameter pipes managing grey water and solid material separated.

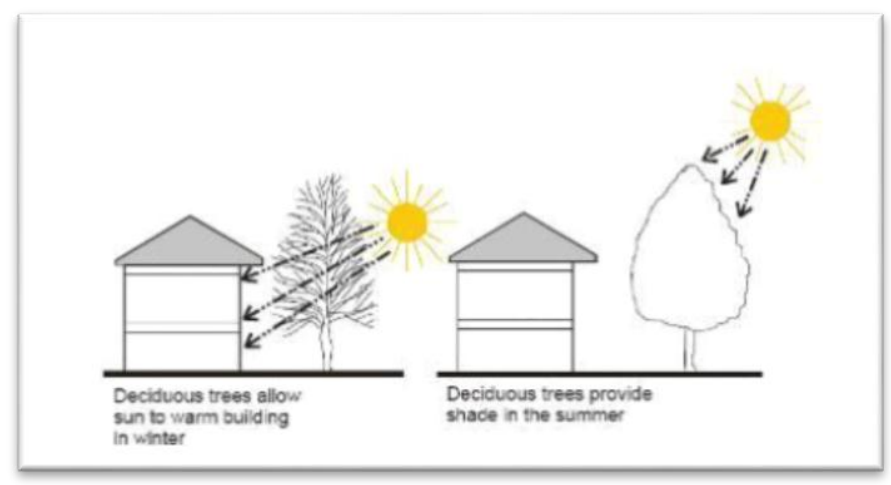

Fig. 8 Example of an effective solar strategy 


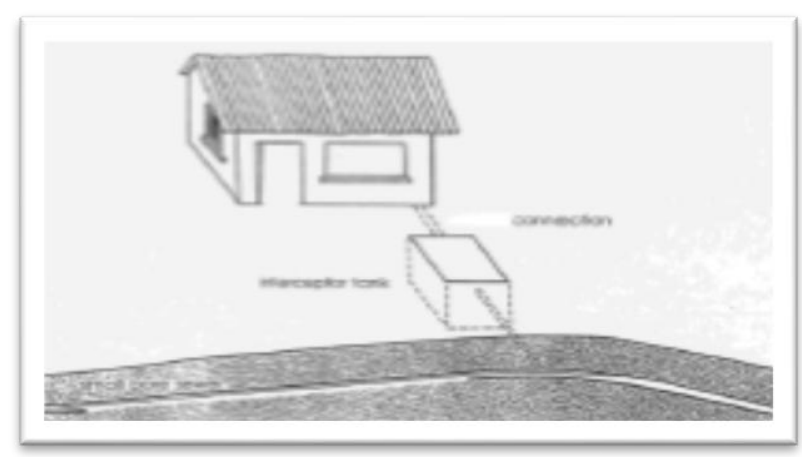

Fig. 9. Small Bore Sewer System

\section{3- Social Performance:}

By comparing social criteria in the case of Innovista with theoretical social performance requirements represented in EIP, we found that:

2-Social infrastructure as shown in table 3:

- $\quad$ Share driveway and/or parking facilities where possible.

- Minimize the size of parking areas and avoid large, barren parking areas.

- Design pedestrian access routes for comfort and safety, Provide pedestrians and cyclists with safe pathways separated from heavy traffic where possible.

- Protect pedestrians from the elements, the use of native plants is preferred.

- Minimize light pollution of the night sky and forested areas by ensuring that lighting is shielded and directed towards the ground.

- Provide parking for small/alternative/carpool vehicles in preferential locations [13].

\section{4- Economic performance:}

By comparing Economic criteria in the case of Innovista with theoretical Economic performance requirements represented in EIP, we found that:

Designated zone for eco-industrial will allow for the industrial development that will demonstrate innovation and high level of environmental and economic performance.

2- Local business and SME Promotion as shown in table 4:

- Targeted economic development strategy that businesses are attracted to fill product.

3- Economic value creation as shown in table 4:

Design buildings to be deconstructed and recycled easily.

Choose materials that: [12]

1- Can be easily recycled at the end of their life.

2- Maintain a high level of indoor air quality in all rooms/covered areas, including low emission finishes.

3- Are "rapidly renewable"

4- Are procured from local manufacturers and/or producers as much as possible.

5- Have been re-used.

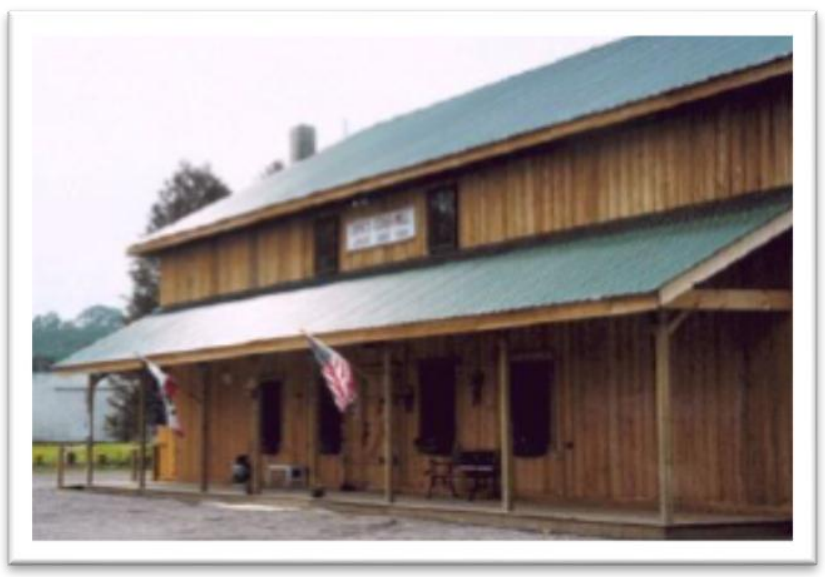

Fig. 10 Example of sloped roof and entry for primary building photo credit: $\mathrm{ABC}$ metal roofing

\section{3-1-3-The benefits of this case study}

There are some features that were not existing in the global system, SIA sustainable industrial area but they were mentioned in the global and successful experiences, and the global system SIA sustainable industrial area did not refer to them. For example:

\section{1- Park management: Performance requirements:}

- A strategic plan for the division of land use indicates the suggested type of development within each phase.

- Clear future vision for extension taking into account expansions due to the expansion of the industry.

2- Environmental: performance requirements:

- Landscape planning and its effect on recommending sorts of planting planning an important role in get rid of harmful in issions (if existed).

3- Social performance requirements:

- Humity aspect in this study such as (shaded paths, pergolas, sitting areas and public spaces).

\section{4- Economic performance requirements}

- Secondary water resources from storm water management pond is integrated with ecological reserve and trail system.

- Natural energy use natural lighting strategies that eliminate lighting energy.

Table .5 - The benefits of this case study (HINTON) (source: author's (2020)

\begin{tabular}{|c|c|c|c|}
\hline $\begin{array}{l}\text { Park management } \\
\text { Performance }\end{array}$ & $\begin{array}{l}\text { Environment } \\
\text { Performance }\end{array}$ & $\begin{array}{c}\text { Social } \\
\text { Performance }\end{array}$ & $\begin{array}{c}\text { Economic } \\
\text { Performance }\end{array}$ \\
\hline $\begin{array}{l}\text { A strategic plan for the division } \\
\text { of land use }\end{array}$ & Landscape planning & landscape maintenance & secondary water resources \\
\hline Clear future vision for extension & & Humity aspect & natural energy \\
\hline
\end{tabular}




\section{3-2-Ulsan Mipoand Onsan industrial park, South Korea}

\section{3-2-1- Industrial park over view [14].}

One of Asia's top 4 manufacturing cities with Korea's largest industrial cluster and home to global companies

Like Hyundai Motors, Hyundai heavy industries, SK Energy, S-OIL, SOLVAY, BASF, DuPont, and BPS sophisticating major industries such as automobile, shipbuilding \& marine, and petrochemical industries

And fostering new industries like battery and energy designated as a special industrial zone in 1962. [15].

Site size: Area of 6,540 hectares, at which 1,000 companies operate.

Variety of industries: vehicle manufacturing, shipbuilding, oil refineries, machineries, non-ferrous metals, fertilizer and chemical industries. More than 100,000 people employed.

Main objective to transform the Mipo-Onsanconventional national industrial complexes into SIA based on the national SIA development master plan[15].

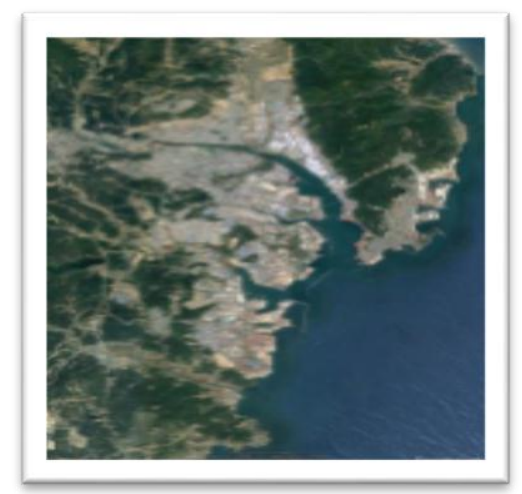

Fig. 11 Aerial photography, by satellite, in Ulsan, Korea.

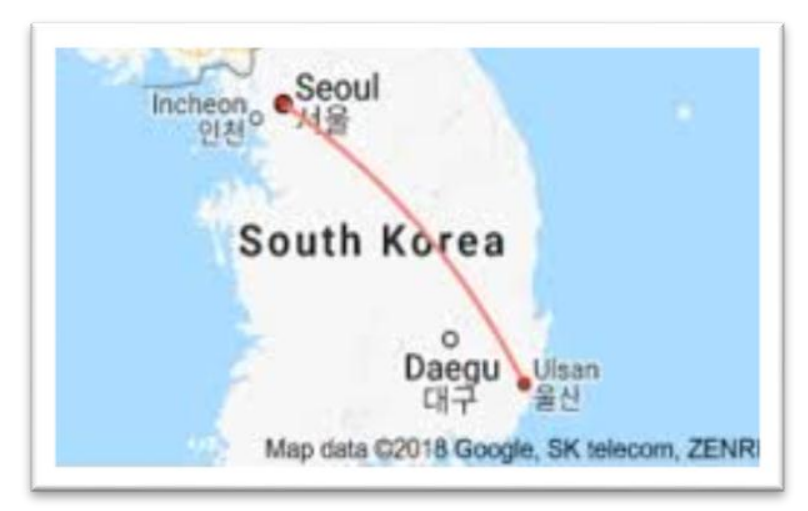

Fig. 12. Ulsan site for Korea SIA Criteria International framework.

\section{3-2-2-Policies supporting eco-industrial Park in Korea}

\section{1- Sustainable development of industrial policy}

Environmentally friendly industrial structure based on institutional system for clean production (CP) an7d environmental management system (EMS) based on ISO 14001 as implementing tools, and "The first comprehensive master plan for environmental friendly industrial development" was made and operated based on apefis. This plan included streamlining the supporting system, CP transfer and dissemination, promoting environmental industry, and stimulating environmental management. [16]

1) Clean production program.

2) O Cleaner production technology development.

3) O CP Technology transfer and dissemination program.

\section{2- Environmental policies stimulating sustainable} development

There are several environmental policies, which stimulate the Sustainable development of industry such as environmental impact assessment (EIA), prior environmental review systems (PERS) and environmentfriendly business Management policies [16].

1) Environmental impact assessment system

2) 2) The prior environmental review system (PERS)

3) 3) Environment-friendly business management policy

\section{3-Industrial symbiosis at Ulsan industrial parks.}

Ulsan industrial complexes were originally developed as conventional industrial estate, with a collective energy provider such as electricity, steam and water. The industrial collaborations in Ulsan complexes were spontaneously occurred by meeting the stringent environmental regulations and economic benefits.

As the concept of EIP has just introduced in korea, the municipality and managers and citizens are gradually interested in by-product exchanges already operated in Ulsan complexes [17].

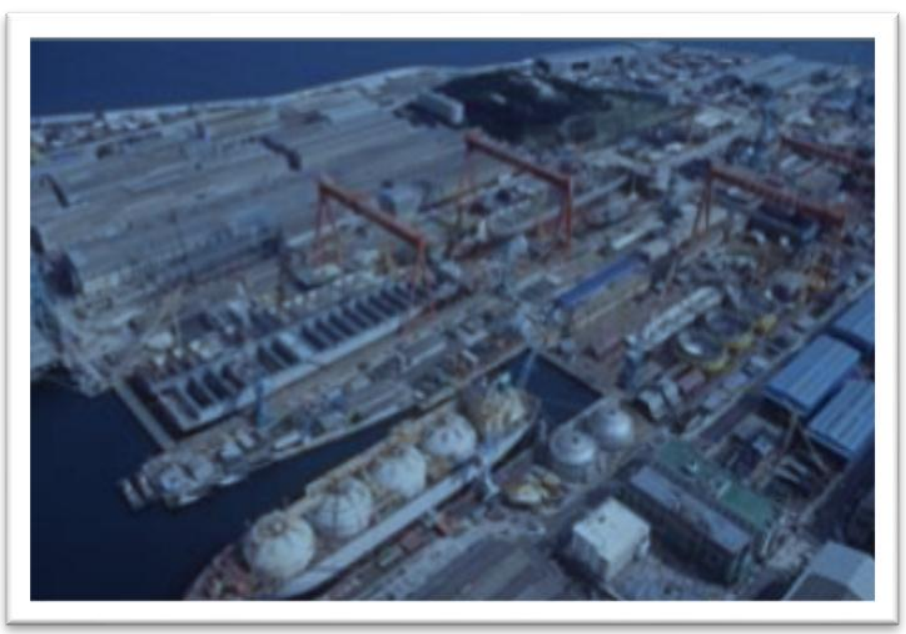

Fig.13. Shipbuilding factories in Korea 


\section{4-Park management and governance structure}

Implemented by the Korea industrial complex corporation (kicox), a semi-governmental body that manages national industrial complexes [17].

- It handles planning, budget accounting, approval of project proposals, and liaison with governmental bodies and concerned organizations.

- Interested in industrial symbiosis project with regard to local context.

- $\quad$ Led by advisory board composed of representatives from local government, academia and industry.

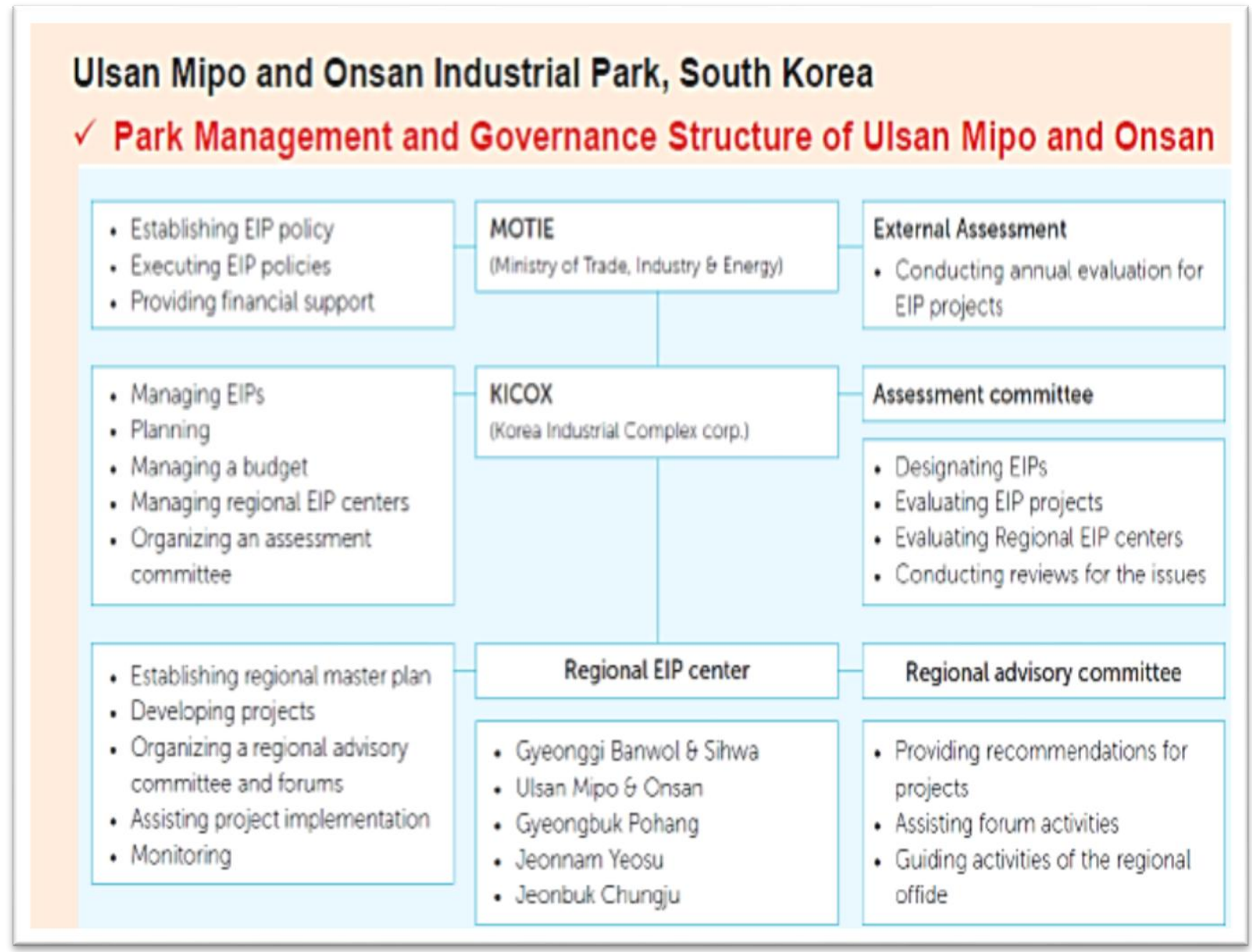

-Fig.14. Industrial park development program Korea: progress and achievements in the phase 2005-2010.

\section{-Country policy environment}

National SIA program launched in 2003 in line with efforts by ministry of trade, industry, and economy to promote innovative industrial development [18].

The 3-stage SIA program adopted a gradual approach to building national eco-industrial networks over 15 years.

1- Establish foundation of program through five pilot industrial sites.

2- Expanding network through a hub and spoke strategy.

3- Establish a national network to integrate industrial complexes and urban areas.

\section{3-2-3--SIA performance and its impacts}

\section{1- Park management performance:}

By comparing management criteria in the case of South Korea with theoretical management performance requirements represented in EIP, we found that:

1-management and monitoring as shown in table 1:

- 77 projects funded for research \& development, 34 for operations, economic, environmental and social benefits are monitored \& resource database for industrial symbiosis [19]. 


\section{2- Environmental performance:}

By comparing environmental criteria in the case of South Korea with theoretical environmental performance requirements represented in EIP, we found that:

2- Energy, 3- water as shown in table 2:

- Benefits evaluated in terms of direct reduction of energy consumption, reduction in waste or byproducts, wastewater, and $\mathrm{CO} 2$ emissions [20].

- Program saved 279,761 tons of oil equivalent, 665,712 tons of $\mathrm{CO} 2$ emissions and 4052 tons of toxic gases, such as Sox and NOx, during 2005-2016.

79,357 tons of water, 40,044 tons of by-products and waste reused. Negative image of complexes as pollution emitters improved, and enhanced relations with local communities.

\section{3- Social performance}

By comparing Social criteria in the case of South Korea with theoretical Social performance requirements represented in EIP, we found that:

1- Management Systems as shown in table 3:

- Private investment for industrial symbiosis networking US\$ 245.8 million (as of 2016), and created 195 new jobs [20].

\section{4- Economic performance:}

By comparing Economic criteria in the case of South Korea with theoretical Economic performance requirements

represented in EIP, we found that:

2- Local business and SME promotion, 3- Economic value creation as shown in table 4:

- The economic benefits were calculated as the sum of cost savings (resource procurement, operations, and environmental/waste management by replacing virgin materials with by-products)

- Revenues (revenues generated by selling by-products) which were annually reported to KICOX since project operations began. Government investments US\$ 14.8 million for R \& D, new income of US\$ 65 million/year selling by-products \& waste for recycling, income of US\$ 78.1 million/year from energy \& was generated from energy and material savings in 2016 [19].

\section{3-2-4-The benefits of this case study}

There are some features that were not existing in the global system, SIA sustainable industrial area but they were mentioned in global and successful experiences, and the global system SIA sustainable industrial area did not refer to them for example:

\section{1- Park management: Performance requirements}

- Database of industrial symbiosis indicate the suggested type of development within each phase.
- How to deal with problems are suffering from shortage of data about future extension for the industrial areas and for land use planning.

\section{2- Environmental Performance requirements}

- Residential areas and its relationship with the industrial area such as (distance between them of $5 \mathrm{~km}$.

, services included, landscaping as fencing).

Landscape. Enhance landscape elements by adding plants that match with landscape elements.

\section{3- Social performance requirements}

Created new jobs

\section{4- Economic performance requirements}

Industrial symbiosis with a collective energy provider such as electricity, steam and water. The industrial collaborations in Ulsan complexes were spontaneously occurred by meeting the stringent environmental regulations and in reduction of the tax benefits.

Table 6. The benefits of this case study (ULSAN) (source: author's (2020)

\begin{tabular}{|c|c|c|c|}
\hline $\begin{array}{c}\text { Park } \\
\text { management } \\
\text { Performance }\end{array}$ & $\begin{array}{c}\text { Environment } \\
\text { Performance }\end{array}$ & $\begin{array}{c}\text { Social } \\
\text { Performance }\end{array}$ & $\begin{array}{c}\text { Economic } \\
\text { Performance }\end{array}$ \\
\hline database & $\begin{array}{c}\text { residential } \\
\text { areas }\end{array}$ & $\begin{array}{c}\text { Created new } \\
\text { jobs }\end{array}$ & $\begin{array}{c}\text { industrial } \\
\text { symbiosis }\end{array}$ \\
\hline $\begin{array}{c}\text { industrial } \\
\text { symbiosis }\end{array}$ & landscape & & taxies \\
\hline $\begin{array}{c}\text { Dealing with } \\
\text { problems }\end{array}$ & & & \\
\hline
\end{tabular}

By comparing $\mathrm{SiA}$ performance requirements Represented in the tables above with theoretical principals of sustainable developments, we found that, there are many benefits did not mentioned in these cases study.

Environmental performance:

- Noise control, monitor natural sites is ignoring.

Social performance:

- Social equity between the resintents from the different social classes,

- Humity aspect in this study such as (shaded paths, pergolas, sitting areas and public spaces),

- Training, staff housing and baby daycare 
International Journal of Engineering Research and Technology. ISSN 0974-3154, Volume 13, Number 11 (2020), pp. $3194-3207$

(C) International Research Publication House. https://dx.doi.org/10.37624/IJERT/13.11.2020.3194-3207

Table 7. EIP prerequisites for park management after modifications (source: author's (2020)

\begin{tabular}{|c|c|c|c|}
\hline Topic & Sub-topic & New Sub-topic & Checklist \\
\hline \multirow{3}{*}{$\begin{array}{l}\text { 1-Park management } \\
\text { Services }\end{array}$} & Park management entity & database & Yes/no \\
\hline & \multirow{2}{*}{$\begin{array}{l}\text { Park property, common } \\
\text { Infrastructure and services }\end{array}$} & industrial symbiosis & \multirow[t]{2}{*}{ Yes/no } \\
\hline & & dealing with problems & \\
\hline \multirow[t]{2}{*}{$\begin{array}{l}\text { 2-Monitoring and risk } \\
\text { management }\end{array}$} & $\begin{array}{l}\text { Monitoring performance } \\
\text { And risks }\end{array}$ & & Yes/no \\
\hline & $\begin{array}{l}\text { Information on applicable } \\
\text { Regulations and standards }\end{array}$ & & Yes/no \\
\hline \multirow[t]{2}{*}{ 3-Planning and zoning } & \multirow[t]{2}{*}{ Master plan } & $\begin{array}{l}\text { a strategic plan for the division } \\
\text { of land use. }\end{array}$ & Yes/no \\
\hline & & vision for extension & Yes/no \\
\hline
\end{tabular}

Table 8. EIP prerequisites for environmental management after modifications (source: author's (2020)

\begin{tabular}{|c|c|c|c|}
\hline Topic & Sub-topic & New Sub-topic & Checklist \\
\hline \multirow{2}{*}{$\begin{array}{l}\text { 1-Management and } \\
\text { monitoring }\end{array}$} & \multirow{2}{*}{$\begin{array}{l}\text { Environmental/energy } \\
\text { Infrastructure and services }\end{array}$} & noise control & Yes/no \\
\hline & & monitor natural sites & Yes/no \\
\hline \multirow[t]{3}{*}{ 2-Energy } & Energy consumption & & Yes/no \\
\hline & $\begin{array}{c}\text { Renewable and clean } \\
\text { energy }\end{array}$ & & Yes/no \\
\hline & Energy efficiency & & Yes/no \\
\hline \multirow[t]{3}{*}{ 3-Water } & Water consumption & & Yes/no \\
\hline & Water treatment & & Yes/no \\
\hline & Water efficiency, reuse and recycling & & Yes/no \\
\hline \multirow[t]{3}{*}{ 4-Waste and material use } & Waste/by-products re-use and recycling & & Yes/no \\
\hline & Dangerous and toxic materials & & Yes/no \\
\hline & Waste disposal & & Yes/no \\
\hline \multirow{2}{*}{$\begin{array}{l}\text { 5-Climate change and } \\
\text { Natural environment }\end{array}$} & Flora and fauna & residential areas & Yes/no \\
\hline & $\begin{array}{l}\text { Air, GHG emissions and } \\
\text { Pollution prevention }\end{array}$ & landscape planning & Yes/no \\
\hline
\end{tabular}


International Journal of Engineering Research and Technology. ISSN 0974-3154, Volume 13, Number 11 (2020), pp. $3194-3207$

(C) International Research Publication House. https://dx.doi.org/10.37624/IJERT/13.11.2020.3194-3207

Table 9. EIP prerequisites for social management after modifications (source: author's (2020)

\begin{tabular}{|c|c|c|c|}
\hline Topic & Sub-topic & New Sub-topic & Checklist \\
\hline \multirow[t]{4}{*}{ 1-Social management $\quad$ systems } & \multirow[t]{4}{*}{ Management team } & created new jobs & \multirow[t]{4}{*}{ Yes/no } \\
\hline & & Social equity & \\
\hline & & Humity aspect & \\
\hline & & Training, & \\
\hline \multirow[t]{3}{*}{ 2-Social infrastructure } & \multirow{3}{*}{$\begin{array}{l}\text { Primary social } \\
\text { Infrastructure }\end{array}$} & staff housing & Yes/no \\
\hline & & landscape maintenance & Yes/no \\
\hline & & baby daycare & Yes/no \\
\hline
\end{tabular}

Table 10. EIP prerequisites for economic management after modifications (source: author's (2020)

\begin{tabular}{|c|c|c|c|}
\hline Topic & Sub-topic & New Sub-topic & Checklist \\
\hline 1- Employment generation & Management team & & Yes/no \\
\hline $\begin{array}{c}\text { 2- Local business and SME } \\
\text { promotion }\end{array}$ & SME development & & Yes/no \\
\hline \multirow[t]{5}{*}{ 3- Economic value creation } & \multirow{4}{*}{$\begin{array}{l}\text { Market demand for EIP } \\
\text { services and infrastructure }\end{array}$} & industrial symbiosis & Yes/no \\
\hline & & secondary water resources & Yes/no \\
\hline & & long-term maintenance & Yes/no \\
\hline & & natural energy & Yes/no \\
\hline & $\begin{array}{l}\text { EIP meets economic } \\
\text { Interests of the government }\end{array}$ & taxes & Yes/no \\
\hline
\end{tabular}

\section{CONCLUSION}

An eco-industrial park or estate is emerging as an alternative to EIP definition, it is a community of manufacturing and service business located together on a common property, which seeks enhanced environmental, economic, and social performance through collaboration in managing in environmental and resource issues.

This research study of (SIA) sustainable industrial area elements on the two cases of the city of Hinton and the ??? Ulsan, it became clear that this global system might be improved as indicated.

For example:

EIP prerequisites for park management after modifications might be improved by adding database, industrial symbiosis to 1-park management services and we can add a strategic plan for the division of land use, future extension to 3-planning and zoning.

For EIP prerequisites for environmental management might be improved by adding noise control, monitor natural sites to 1 management and monitoring and residential areas, landscape to 5-climate change and natural environment.

For EIP prerequisites for social management might be improved by adding training, staff housing, pedestrian movement and baby daycare to 2 -social infrastructure.

For EIP prerequisites for economic management might be improved by adding industrial symbiosis, secondary water resources, long-term maintenance, and natural energy to 3economic value creation.

\section{REFERENCE}

[1] E. A. Lowe, "Eco-industrial park handbook for Asian developing countries," 2001.

[2] N. E. Frosch, R. A., Gallopoulos, "Strategies for manufacturing," Sci. Am., vol. 261, no. 3, pp. 144-152, 1989.

[3] GIZ, 2015. Guidelines for sustainable industrial areas, Version 1.0 (October). Deutsche Gesellschaft für International Zusammenarbeit (GIZ) GmbH, Eschborn, Germany. 
[4] M. R. Chertow, "Industrial symbiosis," Encycl. energy, vol. 3, pp. 407-415, 2004. Proceedings of the ASME 2015 International Design Engineering Technical Conferences \&Computers and Information in Engineering Conference IDETC/CIE 2015August 2-5, 2015, Boston, Massachusetts, USA

[5] H. Shi, M. Chertow, and Y. Song, "Developing country experience with eco-industrial parks: a case study of the Tianjin Economic-Technological Development Area in China," J. Clean. Prod., vol. 18, no. 3, pp. 191-199, Feb. 2010 .

[6] D. Gibbs and P. Deutz, "Reflections on implementing industrial ecology through eco-industrial park development," J. Clean. Prod., vol. 15, no. 17, pp. 16831695, Nov. 2007.

[7] R. R. Heeres, W. J. V Vermeulen, and F. B. De Walle, "Eco-industrial park initiatives in the USA and the Netherlands: First lessons," J. Clean. Prod., vol. 12, no. 8-10, pp. 985-995, 2004.

[8] P. Desrochers, "Industrial symbiosis: The case for market coordination," Journal of Cleaner Production, vol. 12, no. 8-10. pp. 1099-1110, 2004.

[9] The United Nations Industrial Development Organization (UNIDO), the World Bank Group, and Deutsche Gesellschaft fur International Zusammenarbeit (German Development Cooperation) (GIZ) GmbH.

[10] "SIA Criteria International Framework" -Initial Training Agenda - Dr. Michael Weber Cairo, 2019-09-24/25

[11] Innovista eco-industrial park development guidelines Hinton, Alberta December 2011

[12] Hinton strongly recommends an Integrated Design Process for developments in Innovista. Please see the Developer's Resource Kit at www.Innovista.hinton.ca or in our office for more information regarding this process.

[13] B-8 A guide to eco-business zone planning \& development - appendix

[14] Park et al. (2015): A review of the National Eco-Industrial Park Development Program in Korea: Progress and achievements in the first phase, 2005-2010).

[15] Strategies for sustainable industrial development in Ulsan, South Korea: From spontaneous evolution to systematic expansion of industrial symbiosis. http://www.sciencedirect.com/science/article/pii/ S0301479707000175.

[16] Evolution of 'designed' industrial symbiosis networks in the Ulsan Eco-Industrial Park: 'Research and development into businesses as the enabling framework. http://www.sciencedirect.com/science/article/pii/ S0959652612000832.

[17] A review of the National Eco-Industrial Park Development Program in Korea: Progress and achievements in the first phase, 2005-2010. https://ac.elscdn.com/S0959652615012160/1-s2.0-

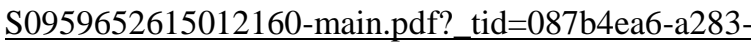

11e7-bdb5-

b0f27\&acdnat=1506407112_ed1da04053f9373ec5eb13a $2 \mathrm{c} 1753 \mathrm{c} 50$

[18] Securing a Competitive Advantage through industrial symbiosis development. http://onlinelibrary.wiley.com/ doi/10.1111/jiec.12158/pdf

[19] Greening Industrial Parks — a Case Study on South Korea's Eco-Industrial Park Program. Www. reengrowthknowledge.org/sites/default/files/downloads/ best-practices/GGGI\%20Case\%20Study_ South\%20Korea\%20EcoIndustrial\%20Park\%20Program_June\%202017.pdf

[20] An International Framework for Eco-Industrial Parks December 2017. 